\title{
COVID-19 as Factor of Influence on the Legislation, Law-Enforcement and Contractual Practice and Change of the Institutional Environment of Economy
}

\author{
Shkalenko A.V. Tymchuk Yu.A." \\ Volgograd State University, Volgograd, 400062, Russia \\ *Corresponding author.Email: oponir@volsu.ru,lavra.ne@mail.ru
}

\begin{abstract}
The article provides an overview of the impact of the coronavirus (COVID-19) pandemic on domestic legislation, contractual and law enforcement practices. The increase in the demand for digital technologies has been substantiated in the context of measures taken by the state to prevent the spread of coronavirus infection. Identified and considered new trends in contractual practice, including such as: preferential conclusion of contracts through electronic form, including through the exchange of documents and on the websites of online stores (online contracts concluded through click-wrap); an increase in the number of online contracts concluded between sellers and buyers-consumers on the websites of stores on the Internet that are involved in grocery retail and fashion retail, namely, retail sale and purchase agreements on the basis of a public offer, including with the condition of contactless delivery. The possibilities of legal qualification of the coronavirus as a force majeure, a circumstance that makes it impossible to fulfill obligations, a significant change in circumstances, including taking into account the judicial practice available at the time of writing, were considered. The expediency of online settlement of disputes arising in connection with non-fulfillment of contractual obligations has been proven. The legislative innovations that have led to a change in the procedure for the execution of certain types of civil law contracts (lease agreement for state or municipal real estate, contracts for the provision of services, an agreement for the provision of educational services), as well as influencing the implementation of corporate procedures, were analysed. Based on the results of the study, the interdependence was determined between the level of implementation of digital technologies in public administration, the judicial system, economic activities of business entities and the ability to adapt to current activities in these areas in the context of the spread of coronavirus. The trends of changes in the institutional environment from the point of view of the short and long term are outlined.
\end{abstract}

Keywords: contractual practice, institutional environment, digitalization, legal fact, force majeure,

significant change in circumstances, transactions

\section{INTRODUCTION}

While the world is still struggling with the COVID-19 pandemic, we are already seeing the impacts that have affected national and global economies and legal regulations, as well as structures, organizations and the management of operations and supply chains. In particular, a certain consensus is observed among reputable experts, analysts and scientists $[1 ; 2 ; 3 ; 4]$ that the pandemic has undermined the "global value chain" model - the production network paradigm that has deeply characterized the world economy over the past 30 years and has been one of the most visible "trademarks" of globalization. This likely restructuring of supply chains will be determined by both managerial (that is, at the firm level) and political (that is, subnational, national or supranational) factors, and will also have an impact on changing consumption patterns in society and accordingly change the order of contractual relations between actors.

\section{METHODOLOGY}

This study is based on the use of elements of an innovative methodology of post-institutional analysis based on interdisciplinary synthesis, which involves overcoming the monoaspectuality, dichotomousness and dogmatism of many concepts of orthodox neoinstitutionalism. Also, the authors used general scientific methods, including dialectical, inductive, deductive, predictive, and specific scientific methods, such as formal legal, the method of legal interpretation, the principle of evaluating legal processes, etc. 
In the course of the research, the author used general scientific methods, including dialectical, inductive, deductive, predictive, analysis, synthesis, induction, deduction and specific scientific methods, such as formal legal, the method of legal interpretation, the principle of assessing legal processes, etc.

The theoretical basis of the research integrated the works of Russian and foreign researchers, legal scholars and economists. The regulatory framework of the study was formed by regulatory legal acts (federal laws, decrees of the President of the Russian Federation, Resolutions of the Government of the Russian Federation, bylaws of ministries and departments, regulatory acts of the constituent entities of the Russian Federation and municipalities, etc.) and the drafts thereof.

\subsection{COVID-19 as a factor deepening the civil turnover digitalization processes}

The COVID-19 pandemic was an unprecedented demonstration of how devastating its effects can be. It is hard to believe that business managers can simply re-focus solely on efficiency and growth without paying due attention to risk-based practices, especially when one considers that the pandemic came so unexpectedly in the turbulent context of the protectionist policies; and growing pressure on more sustainable business models. The specificity of the considered type of legal fact, in conjunction with the protective and preventive measures taken at the state level to prevent the spread of coronavirus infection, naturally influenced the current activities of business entities, during which they inevitably enter into legal obligations drawn up by various types of civil contracts.

Considering that the main ways of spreading a new coronavirus infection are airborne droplets, through dirty hands/objects and water, it becomes an objective necessity to limit contact with other people as much as possible (the so-called self-isolation regime), as well as to observe hygiene rules [5]. In this connection, both the satisfaction of the needs of citizens through the conclusion of small household transactions and the conduct of current economic activities by legal entities by individual entrepreneurs is most expedient to carry out in a contactless way during the outbreak of coronavirus, as a result of which the demand for digital technologies increases.

In the context of this study, we are talking about a deep and large-scale transition to electronic commerce (ecommerce), which, according to experts, is one of the main indicators of the digitalization of the economy [6]. Researchers, considering issues related to e-commerce, often use the term online contract, which is understood as "paperless agreements that are concluded instantly using technical means of communication without the physical presence of the parties and virtually without the ability for one of the parties to agree on the terms of the contract" [7]. In the legal literature, when considering indirect ecommerce, there are two types of the most common transactions (online contracts) concluded in the course of its implementation. They are specified as follows: 1) transactions made through the use of electronic networks as a means of communication [8];2) transactions made through the use of specific means available only in the electronic space [9]. It seems that the criterion underlying this classification is the method of concluding a contract.

So, in the context of restrictive preventive measures, both on the territory of Russia and other countries with an unfavorable epidemiological situation, it is possible to assume that such a method of concluding civil contracts (which is fully consistent with paragraph 2 of article 434 of the Civil Code of the Russian Federation) as an exchange of documents, including by e-mail or drawing up one electronic document signed by the parties will be quite popular among subjects of civil circulation. At the same time, it also requires compliance with the provisions of clause 1 of Article 160 of the Civil Code of the Russian Federation in order for the written form of a transaction made using electronic and other technical means to be considered observed.

It is predicted that the most popular among the subjects of civil circulation will be transactions made through the use of specific means available only in the electronic space. Let us consider this thesis using the example of such an ecommerce model as B2C (business-to-consumer), for which we turn to the websites of online stores popular in the Russian segment of e-commerce, which are involved in grocery retail and fashion retail.

In particular, on the websites of popular online stores (Wildberries [10], Lamoda [11], H\&M [12], Ozon [13], Utkonos [14], etc.) there are public offers that contain the basic conditions for the sale of goods on the website of the online store, including the definition of key concepts, the subject of the contract, the moment of its conclusion, the rights and obligations of the parties, delivery conditions, etc. At the same time, the public offer in a number of cases contains an indication that the contract concluded on the basis of acceptance by the buyer of the offer is a contract of adhesion.

As for determining the method of concluding online contracts in this example, here the contract on the website of the online store is concluded by clicking the consumerbuyer on the button "I agree with the terms of the Public Offer (User Agreement)". Accordingly, based on the approaches existing in the legal doctrine, click-wrap can be considered a way to conclude an online contract.

Interestingly, in the new conditions, some online stores, in order to prevent the spread of coronavirus infection, have introduced an additional method of delivering goods, namely contactless courier delivery. This approach fully meets the current circumstances and correlates with clause 2 of article 499 of the Civil Code of the Russian Federation. In addition, exercising the rights provided for in paragraph 1 of Article 502 of the Civil Code of the Russian Federation, and, despite the imperatively formulated in paragraph 1 of Article 25 of the Law dated 07.02.1992 No. 2300-1 "On Protection of Consumer Rights", the rule on the return/exchange period goods, a number of online stores (mainly fashion retail) have increased the return/exchange 
time for goods purchased online from 30 to 60 days and 90 days. This circumstance also increases the attractiveness of online contracts for consumers.

To date, the legal event in question has led to a significant increase in the number of online contracts concluded, especially in such a segment of e-commerce as B2C (business to consumer) [15].

It is noteworthy that the outbreak of coronavirus infection has led to a revision of the domestic legislator's approach to the retail sale of such special goods as pharmaceuticals. In particular, prior to the events in question, the remote sale of medicines was actually prohibited [16] (it was only possible to reserve the necessary medicine on the websites of pharmacies). However, since 17.03.2020, in connection with the adoption of the Decree of the President of the Russian Federation No. 187 [17], remote retail sale of the over-the-counter medicines is allowed. In foreign countries, similar trends are observed. In addition, the Bank of Russia, realizing the high importance of online trading in the new environment, has decided to limit the maximum value of acquiring commissions for online purchases, which will have a positive impact on the dynamics of online trading [18].

The COVID-19 pandemic also had a significant impact on the execution of civil contracts, including foreign trade transactions. In particular, in connection with the established preventive and prophylactic measures aimed at preventing the spread of coronavirus infection, there are risks associated with both violation of the terms of execution of contracts caused by the extreme difficulty of implementing its terms, which at the time of conclusion could not be foreseen, and with the absolute impossibility execution of the contract.

The domestic civil law doctrine, legislation and law enforcement practice are aware of several civil law institutions, which, in the conditions under consideration, acquire special relevance. We are talking about institutions of: 1) force majeure - clause 3 of article 401 of the Civil Code of the Russian Federation; 2) impossibility to fulfill obligations - Articles 416, 417 of the Civil Code of the Russian Federation; 3) a significant change in circumstances - Article 451 of the Civil Code of the Russian Federation.

Let us consider in more detail the prospects for the application of the norms of each institution in the context of the problem of the execution of civil contracts.

In Russian legislation and judicial practice, criteria have been developed that allow one or another legal event to be classified as force majeure. Among them are the criteria of emergency and inevitability, the interpretation of which is given in clause 8 of the Resolution of the Plenum of the Supreme Court of the Russian Federation of 03.24.2016 No. 7. Based on these approaches, the position of the Chamber of Commerce and Industry of the Russian Federation, as well as the authorities of individual constituent entities of the Russian Federation and municipalities, boils down to recognizing the coronavirus as a force majeure circumstance for the execution of contracts, which actually excludes liability for violation of obligations. According to clause 3 of article 401 of the Civil Code of the Russian
Federation, the impossibility of fulfilling obligations as a result of force majeure is subject to proof. In this regard, it seems that the qualification of specific circumstances as force majeure is the competence of the judicial authorities, and not of the executive authorities, and, based on the provisions of Article 3 of the Civil Code of the Russian Federation, the court cannot be bound by the conclusions contained in the indicated decree. In addition, depending on the characteristics and circumstances of a particular case, it is possible to apply the provisions of Article 451 of the Civil Code of the Russian Federation on a significant change in circumstances.

Speaking about the qualification of coronavirus infection as a force majeure circumstance, one should remember the need to comply with the force majeure clause enshrined in the contract.

As a rule, it is common in contractual practice to stipulate in a force majeure clause the term for sending a notification to the counterparty (for example, to inform the counterparty about the occurrence of force majeure circumstances within 10 days from the date of their occurrence). In the conditions under consideration, associated with the spread of coronavirus infection, it is clearly rather difficult to determine the beginning of the notification period. At the time of this writing, many subjects of the Russian Federation did not recognize the coronavirus infection as a force majeure circumstance. If this does not happen, then the counterparty who violated the contractual terms in connection with the COVID-19 pandemic will have a chance, relying on Article 451 of the Civil Code of the Russian Federation, to prove the fact of a significant change in circumstances.

It should be noted that in such conditions, due to the objective need for the settlement of disputes that may inevitably arise between counterparties in connection with improper performance of obligations, it is advisable, in our opinion, to turn to alternative methods of dispute resolution, namely, online dispute resolution. (Online dispute resolution - ODR) [19].

Online dispute resolution becomes especially relevant during the period of temporary restrictions imposed in Russian courts on visiting courts and holding court sessions [20]. If the counterparties come to the conclusion that it is impossible to resolve the dispute that has arisen and the need to apply for its resolution to the court, then for the period of introducing restrictive measures, the use of digital services such as "My Arbitrator" [21] (when applying to state arbitration courts) or "Electronic justice" [22] (when applying to the courts of general jurisdiction) seems to be one of the most convenient ways of filing statements of claim and other documents in court (in comparison with mailing).

It is also possible to predict an increase in the demand for online dispute resolution among subjects of foreign trade transactions that are geographically located in different states, including those in which an unfavorable epidemiological situation is observed due to the high level of spread of coronavirus. Accordingly, despite the more complicated conditions for doing business and foreign trade, online dispute resolution will allow you to quickly 
resolve the problems arising from the execution of contracts.

As for the possibility of qualifying COVID-19 from the standpoint of Articles 416, 417 of the Civil Code of the Russian Federation as circumstances precluding the possibility of fulfilling obligations, in our opinion, the choice of such an approach will be determined by the specifics of a particular case. For example, in the case provided for in Article 417 of the Civil Code of the Russian Federation, the issuance of an act by a government authority prohibiting entry or exit from the territory of the state, prohibition of transportation, etc. in order to prevent the spread of coronavirus infection may be an obstacle to the execution of certain types of contracts (in particular, supplies, provision of services, etc.), for which the place of execution of the transaction or the personality of the contractor is of decisive importance.

\section{RESULTS}

From a theoretical point of view, the possibility of recognizing COVID-19 as an absolute or relative legal event is primarily due to the official position of the authorities on the source, causes and nature of its occurrence. Based on the currently existing official versions of states about the origin of coronavirus infection, this legal event should be regarded as absolute.

The absolute nature of the legal event under consideration predetermines the emergence of the corresponding legal consequences in various industries, institutions and spheres of activity that are mediated by law. At the same time, it should be noted as well that there is the diversity of public relations regulated by the norms of law, on which the outbreak of coronavirus infection has had a significant impact. In the context of this study, civil law relations are of primary interest.

The outbreak of COVID-19, which, according to the classification of legal facts known in the legal theory, should be attributed to an absolute legal event, the occurrence of which does not depend on the will of a person, had a massive impact on most public relations regulated by the rules of law. The specificity and features of the coronavirus in terms of its ways and time of spread, as well as a number of consequences in the form of high morbidity and mortality among the population, have led to the recognition of its outbreak as a pandemic at the global level. The spread of COVID-19 in Russia has become a catalyst for a whole range of legislative innovations, which are aimed both at preventing morbidity and preventing its spread, and at supporting entrepreneurial activities, whose subjects have suffered serious financial losses under the new conditions. In addition to serious restrictions on the rights and freedoms of citizens and legal entities, which were adopted by state bodies in order to prevent and prevent the spread of infection, COVID-19 had a significant impact on the dynamics of civil turnover, which is expressed in various civil transactions. In turn, the latter are a traditional attribute of both entrepreneurial activity and the ordinary life of individuals who satisfy everyday household needs.
The objective need for a wider use of digital contactless technologies to prevent the spread of coronavirus has influenced the procedure and methods for the execution of certain types of civil contracts (for example, a contract for the provision of educational services, a contract for the provision of services and other contracts in which the person or place of execution of the transaction is important value, lease agreement for state or municipal real estate), as well as for the implementation of corporate procedures (in particular, holding a meeting of shareholders in absentia). In judicial practice, approaches to the legal qualification of coronavirus are not formulated as well. An analysis of the judicial practice of commercial courts at the time of this writing allows to conclude that the courts are cautious in assessing the positions in the case in which the parties refer to the coronavirus. At the same time, most of the rulings on the postponement of court hearings adopted after the publication of the Resolution of the Presidium of the RF Supreme Court and the Presidium of the Council of Judges of the RF No. 808 dated 18.03.2020 are based on the need to comply with preventive measures to prevent the spread of coronavirus.

On the economic front, it is now clear that businesses and individuals will respond with evolving, reactive and often uncoordinated actions that are likely to have cascading financial consequences. A recent article by the Harvard Business Review [23] describes three ways this pandemic is affecting the global economy: a) direct impact on consumer confidence; b) indirect impact on trust (wealth effect); and c) supply shock. The first two mechanisms directly affect consumer and business demand, while the third causes supply disruptions that will take longer to normalize due to increased volatility.

\section{CONCLUSION}

The current situation sets several tasks for the very near future in the field of formatting the institutional environment of the economy and the right field. The proposed solutions will be developed in two different time frames: short term and long term. In the short term, companies and governments will simply react to the current situation, using restructuring to redefine their current operations without making any significant changes to their future strategy. From this perspective, reorganization will simply be a way to cope with the current environment, where companies can either face a temporary state before returning to normal or adapt to a new normal life. Other organizations will look at the situation in the long term, radically changing their strategy. We do not claim that this is due to a radical change in the environment, but the current situation has accelerated the already developing processes of digitalization and the introduction of Industry 4.0 technologies, which was already happening, but at a much slower pace [24]. In this case, a new reality will be established [25]. In the long term, we expect to see two different approaches to reorganization, depending on the level at which the decision-making process takes place: one firm or a supply chain. In terms of political change, we 
expect to see action at both levels. Single-firm policies are easier to implement, more popular in a strictly political sense, but potentially fail to address the challenges faced by most industries during the COVID-19 pandemic. Focusing on the perspective of the supply chain can be critical in coping with sudden changes and increasing its resilience, responsiveness and resilience. In addition, additional difficulties may arise in the implementation of the entire supply chain within the borders of one country; for this reason, cooperation with countries located in close macroregions can become a turning point in favor of developing relationships.

The study of the impact of COVID-19 on legislation, contractual and law enforcement practice allows us to conclude that the demand for modern digital technologies in new unforeseen conditions is increasing significantly. Accordingly, it is possible to recognize that the possibility of their adaptation to current activities in the context of the spread of coronavirus depends on the level of development and the success of the implementation of digital technologies in public administration, the judicial system, and the economic activities of business entities.

\section{ACKNOWLEDGEMENT}

The work was supported by Russian Science Foundation (project №18-78-10075).

\section{REFERENCES}

[1] Javorcik B. Global supply chains will not be the same in the post-COVID-19 world. In Baldwin RE, Evenett SJ (Eds.), COVID-19 and Trade Policy: Why Turning Inward Won't Work, CEPR Press. 2020. pp 111-116

[2] The Economist Intelligence Unit. The great unwinding Covid-19 and the regionalisation of global supply chains. 2020

[3] UNCTAD Impact of the Coronavirus Outbreak on Global FDI, 2020. available at: https://unctad.org/en/PublicationsLibrary/diaeinf2020d2 _en.pdf

[4] World Economic Forum Here's how global supply chains will change after COVID-19. 2020 Available at: https://www.weforum.org/agenda/2020/05/this-is-whatglobal-supply-chains-will-look-like-after-covid-19/ (accessed 4 August 2020)

[5] Recommendations for the prevention of new coronavirus infection», Rospotrebnadzor, available at:https://rospotrebnadzor.ru/about/info/news_time/new s_details.php?ELEMENT_ID=13566 (accessed 31 June 2020).
[6] Drozdova, T., E-commerce as the main indicator of the digitalization of the economy, Commercial Director, available at: https://www.kom-dir.ru/article/2710elektronnaya-kommertsiya (accessed 30 July 2020).

[7] Muratova, O., Concept of Transnational Consumer Law in the Modern World, Lex rusica, 2019, no. 7, pp.20 $-28$.

[8] Kozlovskaya, S.V. Problems of civil regulation of transactions concluded in the framework of electronic interaction, The experience of civil law research: Sat. Art., Moscow, 2018.

[9] Kucher, A.N. Theory and practice of the precontracted phase: legal aspect, Moscow, 2005.

[10] Public offer, Wildberries.ru - a fashionable online store of clothes, shoes and accessories, available at:https://www.wildberries.ru/services/publichnayaoferta?_ga=2.218553177.1714907129.15848126852096793092.1540659708 (accessed 15 June 2020).

[11] User agreement, Lamoda, available at: https://www.lamoda.ru/about/oferta/?from=footer (accessed 15 June 2020)

[12] Terms and Conditions, $\mathrm{H} \& \mathrm{M}$, available at: https://www2.hm.com/en_en/customer-service/legaland-privacy/terms-and-conditions.html (accessed 15 June 2020).

[13] Terms of sale of goods for individuals in OZON.ru», OZON.ru., available at: https://docs.ozon.ru/common/pravila-prodayoi-irekvizity/usloviya-prodayoi-tovarov-dlya-fizicheskihlits-v-ozon-ru (accessed 15 June 2020)

[14] Information, Platypus, available at: https://www.utkonos.ru/doc/info (accessed 31 March 2020).

[15] Online retailers have dramatically increased sales of products and increased delivery times, Interfact, available at: https://www.interfax.ru/russia/699424 (accessed 31 August 2020).

[16] Letter of the Rospotrebnadzor, On the suppression of offenses with the remote method of selling goods, 08 April 2020, No. 0100 / 2569-05-32, ATP Consultant Plus.

[17] Decree of the President of the Russian Federation, On the retail sale of pharmaceuticals for medical use, 17 March 2020, No. 187, Collection of legislation of the Russian Federation, No. 12, Article 1742. 
[18] Information of the Bank of Russia, The Bank of Russia approved additional measures to support citizens, the economy and the financial sector in the context of the coronavirus pandemic, 2020, ATP Consultant Plus.

[19] Inshakova A.O., Tymchuk Y.A., Digital technologies of alternative dispute resolution methods: foreign practice and prospects of application in Russia, Law and Management. XXI Century, no. 1, 2019, pp. 2331.

[20] Resolution of the Presidium of the Armed Forces of the Russian Federation and the Presidium of the Council of Judges of the Russian Federation of March 18, 2020 No 808», The Supreme Court of the Russian Federation, available

at: https://www.vsrf.ru/press_center/news/28815/(accessed 20 March 2020).

[21] Information System «My Arbitrator», Federal Arbitration Courts of the Russian Federation, available at: https://my.arbitr.ru/ (accessed 22 March 2020).

[22] Service «Electronic Justice, GAS RF Justice, available at: https://ej.sudrf.ru/ (accessed 22 March 2020).
[23] Carlsson-Szlezak, P., Reeves, M., \& Swartz, P. (2020). What coronavirus could mean for the global economy. Harvard Business Review. Retrieved March 15, 2020, from https://hbr.org/2020/03/whatcoronavirus-could-mean-for-the-globaleconomy?ab=hero-main-text.

[24] Lavrentyeva, A. V.; Kalinina, A. E.; Frolov, D. P. Institutional anomalies of developing new generalpurpose technologies in the early period of digital economy in Russia. Proceedings of the 2 nd international scientific conference on new industrialization: global, national, regional dimension (SICNI 2018) Book series: Advances in Social Science Education and Humanities Research. 2019, T. 240, pp.: 797-801.

[25] Frolov, D. P.; Lavrentyeva, A. V. Regulatory Policy for Digital Economy: Holistic Institutional Framework. MONTENEGRIN JOURNAL OF ECONOMICS. 2019. T. 15, Vol. 4, pp. 33-44. DOI: 10.14254/1800$5845 / 2019.15-4.3$ 